\title{
Efficacy of nano calcium silicate (NCS) treatment on tropical soils in encapsulating heavy metal ions: leaching studies validation
}

\author{
Syed Abu Sayeed Mohammed ${ }^{1} \cdot$ Arif Ali Baig Moghal ${ }^{2}[$
}

Received: 15 May 2016/Accepted: 11 July 2016/Published online: 19 July 2016

(C) Springer International Publishing Switzerland 2016

\begin{abstract}
Soils are known to retain heavy metals through a number of processes. In this study, four different leaching methods viz. ASTM D3987, toxicity characteristics leaching procedure (TCLP), extended TCLP, and caged TCLP have been used to study the leaching behavior of $\mathrm{Cd}^{2+}, \mathrm{Ni}^{2+}$ and $\mathrm{Pb}^{2+}$ on red and black cotton soils. Further, these soils were amended with nano calcium silicate (NCS). Also, sequential extraction was performed on these soil mixtures to know the extent of sorption taking place in different phases of soils such as exchangeable, oxidizing, reducing, organic content and residual phases. It was found that as per ASTM D3987, all three heavy metals with red soil and black cotton soil were retained well in the short term, and over a long-term period, the metal ion was released back. When amended with NCS, both red soil and black cotton soil exhibited satisfactory retention levels over long periods which proved that NCS was responsible for encapsulation of metal ions in its matrix. To investigate the retention efficiency, extensive leaching tests were performed, and it was found that as per TCLP, extended TCLP and caged TCLP tests, the retention with NCS-amended red earth soil was 88,90 and $94 \%$ compared to untreated case. Sequential extraction proved that encapsulation was durable in NCS-amended soils compared to untreated ones.
\end{abstract}

Arif Ali Baig Moghal

reach2arif@gmail.com

Syed Abu Sayeed Mohammed

abubms@gmail.com

1 Department of Civil Engineering, HKBK College of Engineering, Bangalore 560045, India

2 Bugshan Research Chair in Expansive Soils, Department of Civil Engineering, College of Engineering, King Saud University, Riyadh 11421, Saudi Arabia
Hence, it is concluded that NCS-amended soil is a prospective material to attenuate heavy metals taking into consideration their long-term encapsulation effect in considered soils. This soil NCS mixture is expected to be a potent agent for in situ treatment of brown fields and an excellent substitute for existing conventional landfill liner materials.

Keywords Sorption · Soils $\cdot$ Heavy metals $\cdot$ Nano calcium silicate $\cdot$ TCLP $\cdot$ Sequential extraction

\section{Introduction}

Industrial activities throughout the world have resulted in many contaminated sites. Poor and non-implementation of environmental laws has resulted in uninhabitable sites. Due to urban splurge, many contaminated sites are also being used for human settlements resulting in exposure to harmful chemicals and has resulted in many diseases and sufferings to humans and animals. Soil being a major media for direct contact is known to retain heavy metals through a number of processes, viz., sorption, ion exchange, precipitation, complexation, diffusion, etc. The properties of soils have to be studied so that a sustainable remediation method can be devised to make these contaminated sites safe for human habitation [11, 22]. Also, to dispose heavy metals safely in landfills, the naturally available soils can be used as liner materials to retain heavy metals which will be a sustainable and innovative material to entrap the contaminants in their soil matrices and make them inert. Also, to enhance its retention capacity, a number of soil amendments are available such as lime, cement, flyash, etc. These amendments have their own advantages and disadvantages. In this study, the use of 
nano calcium silicate (NCS) in small concentrations is proposed to be used as a soil amendment. Materials with porous architecture and high surface area are being developed for potential areas of separation science. Nanosized particles have large surface areas relative to their volumes and may have enhanced chemical and biological reactivity. They can be manipulated for specific applications to create novel properties not commonly displayed by particles of the same material at macroscale. Behavior of materials at nanoscale is not necessarily predictable from what we know at macroscale.

At the nanoscale, often highly desirable properties are created due to size confinement, dominance of interfacial phenomena, and quantum effects. Nanocrystalline alkali earth metal oxides evolve interest as innovative material. It is most abundant in nature, highly stale, inert and has wide range of technological applications. Calcium silicate draws significant attention as effective chemisorbents for toxic chemicals and gases. Destructive sorption takes place not only on the surface of these oxide materials but also on their bulk. They work in the destructive sorption reaction most efficiently because of their high surface area and encapsulation phenomenon leaving no room for desorption. Nano calcium silicate (NCS) is a proprietary new material produced by the reaction of silica with calcium ions. NCS comprises single platelets of $5-10 \mathrm{~nm}$ thick and up to $300 \mathrm{~nm}$ across. These self-assemble into particles of about $1-5 \mu \mathrm{m}$ in size with a three-dimensional open framework "gypsum desert rose" type structure. The particles have high pore volume and a high readily accessible surface area of up to about $600 \mathrm{~m}^{2} \mathrm{~g}^{-1}$. The surface of nano size platelets contains both silanol $(\mathrm{Si}-\mathrm{OH})$ groups and $\mathrm{Ca}^{2+}$ ions which collectively provide bonding sites for the adsorption of and functionalization of NCS by various cations [14]. The advantage of using NCS is its ability to encapsulate heavy metals in its newly formed aggregates because of aggregation of soil particles and enclosure/binding with Ca-associated immobile salts so as to render it inert and keep it permanently. It is hypothesized that the addition of NCS would reduce the heavy metal leaching potential from contaminated soil because of its high reduction potential and high surface area [12]. In this study, three heavy metals, cadmium $\left(\mathrm{Cd}^{2+}\right)$, lead $\left(\mathrm{Pb}^{2+}\right)$ and nickel $\left(\mathrm{Ni}^{2+}\right)$ and their interaction with two soils for leaching have been considered. The main aim of this was to study the efficacy of this innovative material so that it can be used for in situ treatment of brown sites and also as a prospective liner material $[1,4,20,31]$.

\section{Materials and methods}

\section{Soils}

Two tropical soils were collected directly from their natural locations namely, red soil (RS) of Bangalore, India from the campus of HKBK College of Engineering $\left(13^{\circ} 02^{\prime} 26.02^{\prime \prime} \mathrm{N}\right.$ and $\left.77^{\circ} 37^{\prime} 40.22^{\prime \prime} \mathrm{E}\right)$ and black cotton soil (BCS) of Belgaum, India from the campus of Visvesvaraya Technological University (VTU) $\left(15^{\circ} 47^{\prime} 7.93^{\prime \prime} \mathrm{N}\right.$ and $74^{\circ} 28^{\prime} 12.53^{\prime \prime} \mathrm{E}$ ) using the standard field sampling methods. The physical and chemical properties of soils were determined, and the USCS (Unified soil classification system) classified it as $\mathrm{CH}$ (clay with high plasticity).

\section{Chemicals used}

The nitrate salts of $\mathrm{Cd}^{2+}, \mathrm{Ni}^{2+}$ and $\mathrm{Pb}^{2+}$ (Merck Limited, Mumbai, India), of analytical grade type have been used to prepare standard solutions using deionized double-distilled water of known concentrations (10, 15, 20, 25, 30, 100, 200 and $1000 \mathrm{mg} \mathrm{L}^{-1}$ ). Similarly, nano calcium silicate (NCS) was synthesized using a proprietary method of authors by combining calcium and silica; the resulting bright white crystalline powder was used in three percentages by weight of soil notated as $\mathrm{X} \%$ with a range of $0.5-2 \%$, respectively, as a soil amendment.

\section{Leaching tests}

In this study, four different leaching methods viz. ASTM D3987-85 (reapproved [2]), toxicity characteristics leaching procedure (TCLP), extended TCLP, and caged TCLP have been used to study the leaching behavior of $\mathrm{Cd}^{2+}$, $\mathrm{Ni}^{2+}$ and $\mathrm{Pb}^{2+}$ on soil and soil amended with nano calcium silicate (NCS) in small percentage. The sequence of leaching tests has been brought out in Fig. 1, which is a flowchart of all the leaching tests performed in this work.

\section{ASTM D3987-85 (reapproved 2012)}

A known weight percentage of heavy metal was mixed as a contaminant (maintaining a load ratio of 50 and $100 \mathrm{mg} /$ $\mathrm{kg}$ ) with soil or soil mixture and allowed to dry naturally for 7 and 28 days in accordance with ASTM D3987-85 (reapproved [2]). The leached solution was collected, and after centrifuging and filtering, the amount of contaminant leached was determined using atomic absorption spectrophotometer (AAS) supplied by PerkinElmer model Analyst 400 . 
Fig. 1 Flow chart of different leaching methods used

\section{Different leaching Tests}

1. ASTM D3987

2. Toxicity Characteristics Leaching Procedure (TCLP)- 1:20 pH 4.93 for untreated soil and 2.88 for treated soil

3. Extended TCLP pH range of 3.5 to 12.5

4. Caged TCLP ( $\mathrm{pH} 4.93)$

Quantification - leachability index and diffusion coefficient, leaching rate

5. Sequential extraction- five phases of soil components

\section{Toxicity characteristics leaching procedure (TCLP)}

According to the USEPA, two types of extraction solutions were used. A $0.1 \mathrm{M}$ acetic acid solution with a $\mathrm{pH}$ of 2.88 was used to extract $\mathrm{S} / \mathrm{S}$ treated samples due to high alkalinity of the NCS-laced soils. An extraction solution comprising $0.1 \mathrm{M}$ acetic acid and $0.0643 \mathrm{M}$ $\mathrm{NaOH}$ with a $\mathrm{pH}$ of 4.93 was used for untreated soils. The waste samples were extracted at a liquid-to-solid ratio of 20 in capped polypropylene bottles on a rotary tumbler at $30 \mathrm{rpm}$ for $18 \mathrm{~h}$. After extraction, the final $\mathrm{pH}$ of the leachate was measured, and the liquid was separated from the solids by filtration through a $0.45-\mu \mathrm{m}$ glass fiber filter.

\section{Extended TCLP}

This test was developed based on the TCLP test to assess heavy metal leachability over a wide range of $\mathrm{pH}$. Ten identical suspensions of TCLP leachant and solid sample at $L / S$ ratio of 20 were prepared in ten bottles. Different amounts of $\mathrm{HCl}$ or $\mathrm{NaOH}$ solution were added to the bottles, so that the final $\mathrm{pH}$ values were distributed between 3.5 and 12.5 .

\section{Caged TCLP}

Cylindrical solidified matrix (monolithic materials) obtained from cured plastic mold containing stabilized samples were cast to specimens with height/diameter ratio of 0.5. These specimens were suspended in a TCLP solution, which was prepared as described above. The samples were placed in a 1-L polyethylene bottles with $500 \mathrm{~mL}$ of
TCLP solution. Cotton thread was acid-washed to remove any contaminants and then washed thoroughly with deionised distilled water. This thread was used to cross-tie the cylindrical specimen (create a cage) and to keep the sample suspended in the polyethylene bottle. A blank containing only $500 \mathrm{~mL}$ of TCLP solution was prepared. Each bottle was then placed on a tumbler; rapid and continuous tumbling (30 rpm) was maintained throughout the experiment at room temperature. The dimensions of the solid material were recorded at $0.5,3,6,24,48$ and $72 \mathrm{~h}$ after starting the experiment, resulting in six leachates with leaching intervals of $0.5,2.5,3,18$ and $24 \mathrm{~h}$. The leachant was refreshed with an equal volume of TCLP solution using a liquid-tosurface area ratio of $10 \mathrm{~mL} / \mathrm{cm}^{2}$. The blank sample remained on the tumbler throughout the experiment. After $72 \mathrm{~h}$, the tumbling was stopped for all the samples including the blank. Both $\mathrm{pH}$ and sample dimensions were taken for all the samples before filtration [8].

Caged TCLP is used to evaluate the release of elements from material that exist as a massive solid. The release of an element is a function of the exposed surface area of a particular volume, whereas the flow-through systems only consider the internal pore surface.

The leaching rate, $(l)(\mathrm{cm} /$ day), of heavy metal (HM) from the monolithic materials can be calculated as:

$l=\frac{a_{n}}{A_{\mathrm{o}}} \frac{V}{S t_{n}}$,

where $V / S$ is the specimen volume/surface area ratio $(\mathrm{cm})$, $a_{n}$ is the amount of HM leached during internal $n(\mathrm{mg}), A_{\mathrm{o}}$ is the amount of HM initially present in the specimen (mg), and $t_{n}$ is leaching time since the beginning of the first leaching interval (hour). 
The cumulative fraction leached (CFC) relative to the total mass of the waste sample was calculated using the following relation:

$\mathrm{CFC}=\frac{\sum a_{n}}{A_{\mathrm{o}}} \frac{V}{S}$

The effective diffusion coefficient or effective diffusivity $(D)$ is a measure of the diffusivity of the heavy metals in the monolith specimen of solidified waste for each leaching interval, and is given by:

$D=\pi\left[\frac{a_{n} / A_{\mathrm{o}}}{\Delta t_{n}}\right]^{2}\left(\frac{\mathrm{V}}{\mathrm{S}}\right)^{2} T$,

where

$T=\left[\frac{1}{2}\left(\sqrt{t_{n}}+\sqrt{t_{n-1}}\right)\right]^{2}$

Leachability index, $L_{\mathrm{i}}$ (dimensionless), gives an indication of the effectiveness of the $\mathrm{S} / \mathrm{S}$ technique for control of leaching, and can be calculated as:

$L_{\mathrm{i}}=\frac{1}{n} \sum\left[\log \left(\frac{\beta}{D}\right)\right]$,

where $\beta$ is a defined contant $\left(1.0 \mathrm{~cm} / \mathrm{s}^{2}\left(\mathrm{~cm}^{2} / \mathrm{s}\right)\right.$ [28].

\section{Sequential extraction procedure (SEP)}

The sequential extraction procedure which operationally groups the sorbed heavy metals onto soils into the following five fractions:

\section{F.1. Soluble and exchangeable}

The soluble and exchangeable metals from soil were extracted with $20 \mathrm{~mL}$ of a $1.0-\mathrm{M} \mathrm{MgCl}_{2}$ solution adjusted to a $\mathrm{pH}$ of 7.0 by mechanical shaking for $1 \mathrm{~h}$ at $20{ }^{\circ} \mathrm{C}$.

\section{F.2. Bound to carbonates}

The carbonates in the residue from the previous step were extracted with $20 \mathrm{~mL}$ of a 1.0-M sodium acetate solution adjusted to a $\mathrm{pH}$ of 5.0 with hydroxylammonium chloride solution by continuously shaking for $4 \mathrm{~h}$ at room temperature.

\section{F.3. Bound to iron and manganese oxides}

Metals bound to iron and manganese oxides were extracted from the residue of the second extraction by shaking with $50 \mathrm{~mL}$ of a $0.04 \mathrm{M}-\mathrm{NH}_{2} \mathrm{OH}$ and $\mathrm{HCl}$ with $25 \%$ hydroxylammonium chloride solution. The extraction was performed at $96 \pm 3{ }^{\circ} \mathrm{C}$ for $5.5 \mathrm{~h}$.

\section{F.4. Bound to organic matter}

Metals bound to organic matter were extracted by pouring $7.5 \mathrm{~mL}$ of a $0.02-\mathrm{M} \mathrm{HNO}_{3}$ solution and $12.5 \mathrm{~mL}$ of a $30 \%$ $\mathrm{H}_{2} \mathrm{O}_{2}$ solution adjusted to a $\mathrm{pH}$ of 2.0 onto the residue from $\mathrm{F} 3$, then providing continuous agitation for $2 \mathrm{~h}$ at the temperature of $85^{\circ} \mathrm{C}$. An additional volume of $7.5 \mathrm{~mL}$ of the $30 \% \mathrm{H}_{2} \mathrm{O}_{2}$ solution adjusted to a pH of 2.0 is then added, while maintaining continuous agitation and a temperature of $85^{\circ} \mathrm{C}$ for another $3 \mathrm{~h}$. This solution was then cooled to room temperature. An aliquot of $12.5 \mathrm{~mL}$ of a $3.2-\mathrm{M}$ ammonium acetate $20 \% \mathrm{HNO}_{3}$ solution was added and shaken for $30 \mathrm{~min}$.

\section{F.5. Bound to the soil matrix (residual fraction)}

The residue from F4 was quantitatively transferred into a digestion vessel, and metals were dissolved in aqua regia using $7 \mathrm{~mL}$ of $10 \mathrm{M} \mathrm{HCl}$ and $2.3 \mathrm{~mL}$ of $15.8 \mathrm{M} \mathrm{HNO}_{3}$. The temperature of the reaction mixture was slowly risen until reflux conditions and maintained for $2 \mathrm{~h}$. Three parallel extractions were carried out, in each case using $2.5000 \mathrm{~g}$ soil. All solid/liquid separations were performed by centrifuging at $5000 \mathrm{rpm}$ for $15 \mathrm{~min}$. The supernatant was removed and analyzed for metals. The residue was washed with $20 \mathrm{~mL}$ of deionized water. After centrifugation for $15 \mathrm{~min}$, the supernatant was discarded. All dilutions were made to $50 \mathrm{~mL}$ with $2 \%$ (v/v) $\mathrm{HNO}_{3}$. For each fraction, a blank was subjected to the same procedure. Finally, the percentage of metal in each soil phase was determined using:

Metal in each soil phase $(\%)$

$=\frac{\text { Contaminant mass in supernatant }\left(C_{1} V_{1}\right) \times 100}{\text { Initial contaminant mass in soil }(\mathrm{CsMs})}$,

where $C_{1}$ and $C_{\mathrm{s}}$ are the concentrations of contaminant in supernatant (in $\mathrm{mg} / \mathrm{L}$ ) and soil (in $\mathrm{mg} / \mathrm{kg}$ ), $V_{1}$ is the volume of supernatant (in L) and Ms is the dry mass of the soil (in $\mathrm{kg})$.

\section{Confirmatory tests}

Confirmatory tests were performed for micro-structural characterization of soil and soil mixtures using SEM and EDAX.

These experimental methods emphasized the use of two tropical soils amended with NCS as an innovative material to retain heavy metals. In this, four leaching tests were performed to extensively study the efficacy of soil NCS mixture in retaining $\mathrm{Cd}^{2+}, \mathrm{Ni}^{2+}$ and $\mathrm{Pb}^{2+}$. Also, to study the type of retention in different phases of soil elements, sequential extraction procedure was performed. Later, 
confirmatory tests were done in terms of SEM and EDAX to ascertain sorption at micro-scale. This elaborate experimental program would give a fair idea of the behavior of soil NCS mixture in retaining heavy metals.

\section{Results and discussions}

\section{Leaching studies}

Sorption is generally used to evaluate the sorbate-sorbent interaction, and the efficiency of sorption is arrived at by performing batch equilibrium tests. In this, the amount of sorbate used in comparison to sorbent is very less and, hence, many a times may not give the actual field conditions such as leachate soil interaction. Under such conditions, leaching tests would provide a wide array of data which would, in turn, help researchers to understand the type of sorption taking place, and this, in turn, could be used to design contaminant retaining systems.

Batch leaching tests were performed as per ASTM D3987, and readings were taken over different curing periods of 7, 14, 28 and 90 days at two load ratios (50 and $100 \mathrm{mg} / \mathrm{kg}$ ). There was a gradual increase in concentration of leached contaminants (Fig. 2). Also, the amount of leaching was more for higher load ratio. The order of leaching was $\mathrm{Ni}>\mathrm{Cd}>\mathrm{Pb}$. This may be due to the reason that standard reduction potential of $\mathrm{Cd}^{2+}$ is $(-0.40)$ and that of $\mathrm{Ni}^{2+}$ is $(-0.26)$, which would mean that $\mathrm{Cd}^{2+}$ is a better oxidizing element than $\mathrm{Ni}^{2+}$. Since $\mathrm{Cd}^{2+}$ is more stable than $\mathrm{Ni}^{2+}$, maximum leaching occurs for $\mathrm{Ni}^{2+}$ than $\mathrm{Cd}^{2+}$. Over a period of time, some of the precipitates are broken down into their elemental forms and introduced back in the solution [13]. Also, it may have been subjected to desorption and, hence, could have got introduced into the solution. The order of leaching for both the soils was
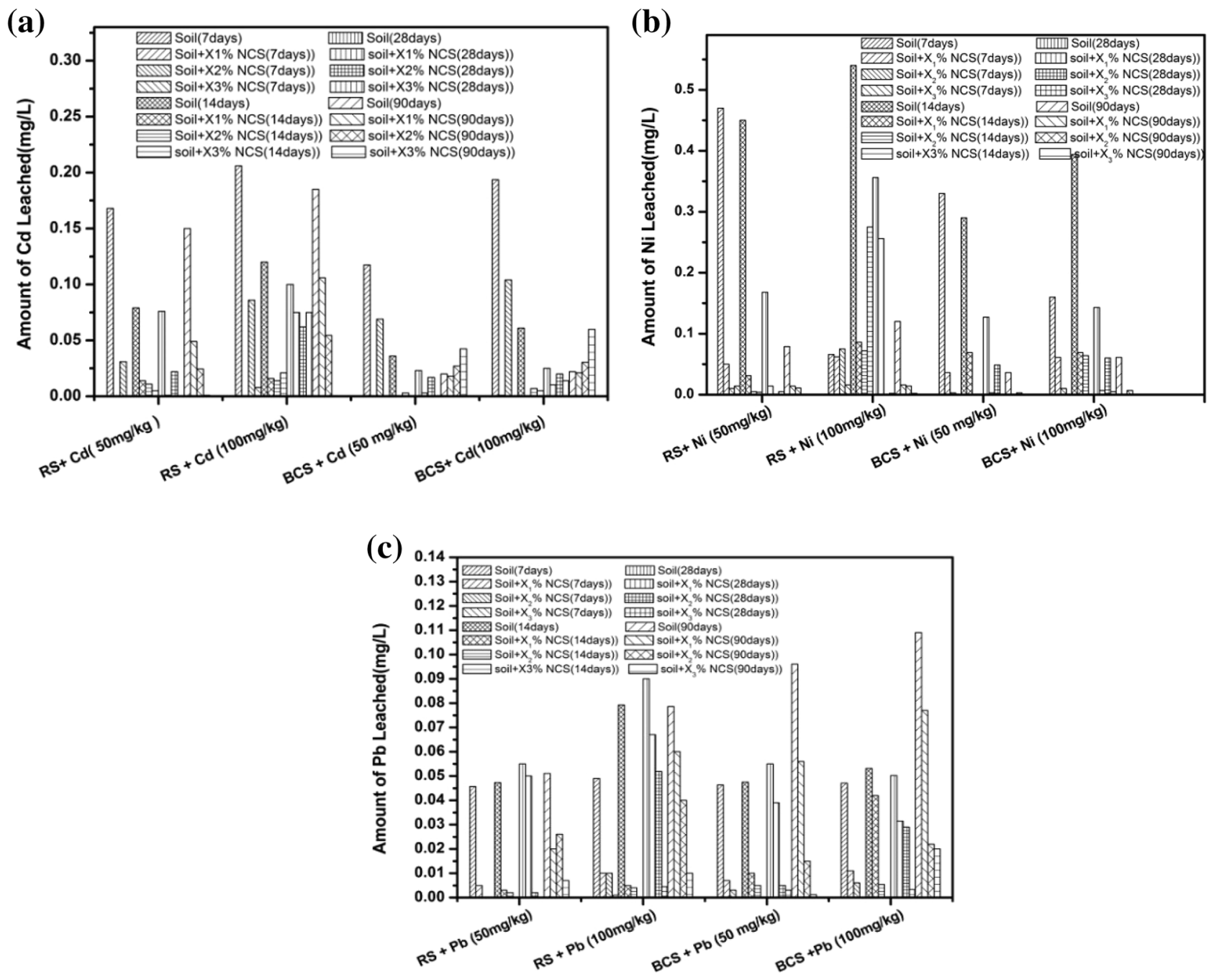

Fig. 2 Leaching behavior of a $\mathrm{Cd}^{2+}, \mathbf{b ~ N i}{ }^{2+}, \mathbf{c} \mathrm{Pb}^{2+}$ as per ASTM D3987 
BCS amended with NCS $<$ RS amended with NCS. This is due to factors such as the presence of large amounts of organic matter in BCS, organic ligand formation and alkaline nature of BCS. Sorption and entrapment in the soil matrix may be predominant, and hence, the degree of leaching in BCS was much lower than RS. This is in conformation with the work of Bhattacharya and Gupta [7] wherein kaolinitic soils leached more than montmorillonitic soils. In the current study, RS is predominantly a kaolinitic soil, whereas BCS is a montmorillonitic soil. It was observed that the contaminated soils did not leach metals in the short term due to strong interactions with soils. However, in the long run, metals were leached from the soil due to their complexation with solubilized organic matter, especially in an alkaline environment where organic matter is more soluble. It has been reported that leaching of $\mathrm{Pb}^{2+}, \mathrm{Cd}^{2+}$ and $\mathrm{Ni}^{2+}$ increased with decreasing $\mathrm{pH}$, although a negligible amount of these elements were also found to leach in alkaline $\mathrm{pH}$ range. In our study, it was observed that the $\mathrm{pH}$ of the leached solution of RS$\mathrm{Cd}^{2+}$ varied from 8 at 28 days to 6.6 at 90 days. Similarly, for BCS- $\mathrm{Cd}^{2+}$ mixture, it varied from 11 at 28 days to 7.5 at 90 days. The $\mathrm{pH}$ of the leached solution of $\mathrm{RS}-\mathrm{Ni}^{2+}$ mixture varied from 11 to 6.3 and $\mathrm{BCS}-\mathrm{Ni}^{2+}$ mixture varied from 8 to 7.2 at 28 to 90 days, respectively [6]. It can be seen that there is acidification of leachate over a period of time. Hence, it can be concluded that an increase in soil $\mathrm{pH}$ will cause immobilization of $\mathrm{Pb}^{2+}, \mathrm{Cd}^{2+}$ and $\mathrm{Ni}^{2+}$ as it is known that at alkaline conditions, metals can precipitate as oxides, hydroxides, carbonates and phosphates. The solubilization of organic complexes can compete with the soil surface for the metal cations and influence metal sorption and release. The stability of the metal complex, in turn, is also pH-dependent. It was observed that over a period of time, virgin soils leached more amounts for contaminants for reasons enumerated above, whereas NCS-amended soils remained stable over long-term periods. This may be due to encapsulation occurring between the soil NCS matrix which has made the contaminant inert from any reaction over a period of time. This increased the efficacy of NCS as a stabilizing material for long-term attenuation requirements of the industry. Further, to validate the use of NCS as a soil amendment, many more leaching tests have been performed under various conditions $[17,18,21]$. It was found that because of the organic nature of BCS and being an expansive soil with low strength parameters, it was decided to continue further tests only with red soil.

Toxicity characteristics leaching procedure (TCLP), extended TCLP, and caged TCLP have been used to study the leaching behavior of $\mathrm{Cd}^{2+}, \mathrm{Ni}^{2+}$ and $\mathrm{Pb}^{2+}$ on red soil and red soil amended with nano calcium silicate (NCS) in small percentage. NCS was synthesized by a proprietary method of the authors. It was found that as per ASTM D3987, all the three heavy metals with red soil was retained well in the short term, and over a long-term period, the metal ion was released back. Red soil was amended with nano calcium silicate (NCS), and it was found that over a period of time, the retention was satisfactory which proved that NCS was responsible for the encapsulation of $\mathrm{Cd}^{2+}, \mathrm{Ni}^{2+}$ and $\mathrm{Pb}^{2+}$ in its matrix [9].

Extensive leaching tests were further performed to validate these results; it was found that as per TCLP (Table 1), extended TCLP (Tables 2, 3, 4) and caged TCLP tests (Tables 5, 6, 7), the retention of heavy metals with amended soil was 88, 90 and $94 \%$ better than soil, respectively. Extended TCLP tests further proved that leaching is better controlled at a $\mathrm{pH}$ range of 9-10. Caged TCLP test quantified the leaching rate which was found to be $0.07 \mathrm{~cm} /$ year for amended soil and $1.01 \mathrm{~cm} /$ year for soil (Tables 5, 6, 7). TCLP methods indicated that the compounds contained in soils could potentially be transferred to the liquid phase depending upon the leaching method used. Heavy metal concentrations were higher in TCLP eluates, indicating that the initial $\mathrm{pH}$ value of the leaching medium significantly affected the transfer of these elements to the liquid phase. In many respects, leaching behavior as reflected by the $\mathrm{pH}$-based leaching tests provide a better means of assessing environmental impact [5]. Hence, it can be concluded that NCS-amended soil is a prospective material to attenuate heavy metals taking into consideration the long-term effect of heavy metals on soils. Further, a non-dimensional leachability index (LI) was calculated based on caged TCLP tests and was found to vary between 2 and 4 for virgin soils, and for soils amended with nano calcium silicate (NCS), it varied between 5 and

Table 1 Leaching behavior with TCLP test for $\mathrm{Ni}^{2+}, \mathrm{Pb}^{2+}$ and $\mathrm{Cd}^{2+}$

\begin{tabular}{|c|c|c|c|c|c|c|c|c|c|c|}
\hline \multirow[t]{2}{*}{ Sl. no } & \multirow{2}{*}{$\begin{array}{l}\text { Heavy } \\
\text { metal }\end{array}$} & \multirow{2}{*}{$\begin{array}{l}\text { Heavy metal } \\
\text { loaded }(\mathrm{mg} / \mathrm{kg})\end{array}$} & \multicolumn{4}{|c|}{ Red soil (RS) } & \multicolumn{4}{|c|}{$\mathrm{RS}+\mathrm{X} \% \mathrm{NCS}$} \\
\hline & & & $\begin{array}{l}\text { Initial } \\
\mathrm{pH}\end{array}$ & $\begin{array}{l}\text { Adj. } \\
\text { pH }\end{array}$ & $\begin{array}{l}\text { Final } \\
\mathrm{pH}\end{array}$ & $\begin{array}{l}\text { Leachate } \\
(\mathrm{mg} / \mathrm{L})\end{array}$ & $\begin{array}{l}\text { Initial } \\
\mathrm{pH}\end{array}$ & $\begin{array}{l}\text { Adj. } \\
\mathrm{pH}\end{array}$ & $\begin{array}{l}\text { Final } \\
\mathrm{pH}\end{array}$ & $\begin{array}{l}\text { Leachate } \\
(\mathrm{mg} / \mathrm{L})\end{array}$ \\
\hline 1 & Nickel & 3010 & 5.1 & 4.93 & 3.16 & 112.4 & 7.8 & 2.9 & 6.36 & 21.63 \\
\hline 2 & Lead & 3015 & 5.125 & 4.91 & 2.9 & 95.51 & 7.58 & 2.84 & 5.88 & 10.25 \\
\hline 3 & Cadmium & 3055 & 5.04 & 4.915 & 2.95 & 106.69 & 7.85 & 2.87 & 6.07 & 59 \\
\hline
\end{tabular}


Table 2 Leaching behavior with extended TCLP for $\mathrm{Cd}^{2+}$

\begin{tabular}{|c|c|c|c|c|c|c|c|c|c|}
\hline \multirow[t]{2}{*}{ Sl. no. } & \multirow[t]{2}{*}{ Heavy metal } & \multicolumn{4}{|c|}{ Extended TCLP for red soil (RS) } & \multicolumn{4}{|c|}{ Extended TCLP for RS + X \% NCS } \\
\hline & & $\begin{array}{l}\text { Initial } \\
\mathrm{pH}\end{array}$ & $\begin{array}{l}\text { Adjusted } \\
\mathrm{pH}\end{array}$ & $\begin{array}{l}\text { Final } \\
\mathrm{pH}\end{array}$ & $\begin{array}{l}\text { Leachate } \\
\text { conc }(\mathrm{mg} / \mathrm{L})\end{array}$ & $\begin{array}{l}\text { Initial } \\
\mathrm{pH}\end{array}$ & $\begin{array}{l}\text { Adjusted } \\
\mathrm{pH}\end{array}$ & $\begin{array}{l}\text { Final } \\
\mathrm{pH}\end{array}$ & $\begin{array}{l}\text { Leachate } \\
\text { conc. }(\mathrm{mg} / \mathrm{L})\end{array}$ \\
\hline 1 & \multirow{10}{*}{$\begin{array}{l}\text { Cadmium } \\
\quad(\text { load } 3055 \mathrm{mg} / \mathrm{kg})\end{array}$} & 5.09 & 3 & 3.52 & 128.8 & 7.89 & 3 & 3.69 & 118 \\
\hline 2 & & 5.09 & 4 & 4.38 & 112.0 & 7.89 & 4 & 4.21 & 78.2 \\
\hline 3 & & 5.09 & 5 & 5.34 & 99.9 & 7.89 & 5 & 6.05 & 29.65 \\
\hline 4 & & 5.09 & 6 & 6.57 & 77.5 & 7.89 & 6 & 7.1 & 6.1 \\
\hline 5 & & 5.09 & 7 & 7.08 & 39.6 & 7.89 & 7 & 7.39 & 0.705 \\
\hline 6 & & 5.09 & 8 & 7.39 & 22.48 & 7.89 & 8 & 7.52 & 0.925 \\
\hline 7 & & 5.09 & 9 & 7.79 & 3.4 & 7.89 & 9 & 7.89 & 0.253 \\
\hline 8 & & 5.09 & 10 & 8.18 & 1.04 & 7.89 & 10 & 8.19 & 0.309 \\
\hline 9 & & 5.09 & 11 & 9.46 & 0.667 & 7.89 & 11 & 9.23 & 0.295 \\
\hline 10 & & 5.09 & 12 & 10.46 & 0.25 & 7.89 & 12 & 11.44 & 0.114 \\
\hline
\end{tabular}

Table 3 Leaching behavior with extended TCLP for $\mathrm{Ni}^{2+}$

\begin{tabular}{|c|c|c|c|c|c|c|c|c|c|}
\hline \multirow[t]{2}{*}{ Sl. no. } & \multirow[t]{2}{*}{ Heavy metal } & \multicolumn{4}{|c|}{ Extended TCLP for red soil (RS) } & \multicolumn{4}{|c|}{ Extended TCLP for RS $+\mathrm{X} \% \mathrm{NCS}$} \\
\hline & & $\begin{array}{l}\text { Initial } \\
\mathrm{pH}\end{array}$ & $\begin{array}{l}\text { Adjusted } \\
\mathrm{pH}\end{array}$ & $\begin{array}{l}\text { Final } \\
\mathrm{pH}\end{array}$ & $\begin{array}{l}\text { Leachate } \\
\text { conc }(\mathrm{mg} / \mathrm{L})\end{array}$ & $\begin{array}{l}\text { Initial } \\
\mathrm{pH}\end{array}$ & $\begin{array}{l}\text { Adjusted } \\
\mathrm{pH}\end{array}$ & $\begin{array}{l}\text { Final } \\
\mathrm{pH}\end{array}$ & $\begin{array}{l}\text { Leachate } \\
\text { conc. }(\mathrm{mg} / \mathrm{L})\end{array}$ \\
\hline 1 & \multirow{10}{*}{$\begin{array}{l}\text { Nickel } \\
\quad(\text { load } 3010 \mathrm{mg} / \mathrm{kg} \text { ) }\end{array}$} & 5.1 & 3 & 6.12 & 145.8 & 7.8 & 3 & 3.65 & 113.8 \\
\hline 2 & & 5.1 & 4 & 6.47 & 137.65 & 7.8 & 4 & 4.21 & 97.56 \\
\hline 3 & & 5.1 & 5 & 7.1 & 108.5 & 7.8 & 5 & 5.05 & 57.16 \\
\hline 4 & & 5.1 & 6 & 7.73 & 103.3 & 7.8 & 6 & 7.09 & 34.62 \\
\hline 5 & & 5.1 & 7 & 7.98 & 93.9 & 7.8 & 7 & 7.52 & 1.68 \\
\hline 6 & & 5.1 & 8 & 8.26 & 7.8 & 7.8 & 8 & 8.85 & 0.176 \\
\hline 7 & & 5.1 & 9 & 8.39 & 1.8 & 7.8 & 9 & 8.88 & 0.181 \\
\hline 8 & & 5.1 & 10 & 8.79 & 0.078 & 7.8 & 10 & 10.02 & 0.098 \\
\hline 9 & & 5.1 & 11 & 9.42 & 2.993 & 7.8 & 11 & 10.49 & 0.214 \\
\hline 10 & & 5.1 & 12 & 10.1 & 5.03 & 8.8 & 12 & 11.29 & 0.519 \\
\hline
\end{tabular}

Table 4 Leaching behavior with extended TCLP for $\mathrm{Pb}^{2+}$

\begin{tabular}{|c|c|c|c|c|c|c|c|c|c|}
\hline \multirow[t]{2}{*}{ Sl. no. } & \multirow[t]{2}{*}{ Heavy metal } & \multicolumn{4}{|c|}{ Extended TCLP for red soil (RS) } & \multicolumn{4}{|c|}{ Extended TCLP for RS $+\mathrm{X} \% \mathrm{NCS}$} \\
\hline & & $\begin{array}{l}\text { Initial } \\
\mathrm{pH}\end{array}$ & $\begin{array}{l}\text { Adjusted } \\
\mathrm{pH}\end{array}$ & $\begin{array}{l}\text { Final } \\
\mathrm{pH}\end{array}$ & $\begin{array}{l}\text { Leachate } \\
\text { conc }(\mathrm{mg} / \mathrm{L})\end{array}$ & $\begin{array}{l}\text { Initial } \\
\mathrm{pH}\end{array}$ & $\begin{array}{l}\text { Adjusted } \\
\mathrm{pH}\end{array}$ & $\begin{array}{l}\text { Final } \\
\mathrm{pH}\end{array}$ & $\begin{array}{l}\text { Leachate } \\
\text { conc. }(\mathrm{mg} / \mathrm{L})\end{array}$ \\
\hline 1 & \multirow{10}{*}{$\begin{array}{l}\text { Lead } \\
\qquad(\text { load } 3015 \mathrm{mg} / \mathrm{kg})\end{array}$} & 5.15 & 3 & 6.12 & 138.2 & 7.56 & 3 & 4.4 & 107.23 \\
\hline 2 & & 5.15 & 4 & 6.47 & 125.2 & 7.56 & 4 & 4.8 & 24.4 \\
\hline 3 & & 5.15 & 5 & 7.1 & 41.22 & 7.56 & 5 & 5.1 & 4.278 \\
\hline 4 & & 5.15 & 6 & 7.73 & 9.3 & 7.56 & 6 & 7.19 & 1.098 \\
\hline 5 & & 5.15 & 7 & 7.98 & 9.8 & 7.56 & 7 & 7.45 & 1.606 \\
\hline 6 & & 5.15 & 8 & 8.26 & 0 & 7.56 & 8 & 7.72 & 1.006 \\
\hline 7 & & 5.15 & 9 & 8.39 & 0 & 7.56 & 9 & 8.78 & 0 \\
\hline 8 & & 5.15 & 10 & 8.79 & 0 & 7.56 & 10 & 8.98 & 0 \\
\hline 9 & & 5.15 & 11 & 9.42 & 1.11 & 7.56 & 11 & 9.9 & 0.639 \\
\hline 10 & & 5.15 & 12 & 10.10 & 2.734 & 7.56 & 12 & 11.60 & 2.529 \\
\hline
\end{tabular}


Table 5 Leaching behavior with caged TCLP for $\mathrm{Cd}^{2+}$

\begin{tabular}{|c|c|c|c|c|c|c|c|c|c|c|c|c|}
\hline \multirow[t]{2}{*}{ S1. no. } & \multirow{2}{*}{$\begin{array}{l}\text { Heavy metal } \\
(\mathrm{mg} / \mathrm{kg})\end{array}$} & \multirow{2}{*}{$\begin{array}{l}\text { Time } \\
\text { (h) }\end{array}$} & \multicolumn{5}{|c|}{ Red soil (RS) } & \multicolumn{5}{|c|}{$\mathrm{RS}+\mathrm{X} \% \mathrm{NCS}$} \\
\hline & & & $\begin{array}{l}\text { Initial } \\
\mathrm{pH}\end{array}$ & $\begin{array}{l}\text { Final } \\
\mathrm{pH}\end{array}$ & $\begin{array}{l}\text { Amount } \\
\text { leached } \\
\mathrm{mg} / \mathrm{L}\end{array}$ & $\begin{array}{l}\text { Leaching } \\
\text { rate in } \\
\mathrm{cm} / \text { year }\end{array}$ & $\begin{array}{l}\text { Diffusivity } \\
\mathrm{cm}^{2} / \mathrm{s}\end{array}$ & $\begin{array}{l}\text { Initial } \\
\mathrm{pH}\end{array}$ & $\begin{array}{l}\text { Final } \\
\text { pH }\end{array}$ & $\begin{array}{l}\text { Amount } \\
\text { leached } \\
\mathrm{mg} / \mathrm{L}\end{array}$ & $\begin{array}{l}\text { Leaching } \\
\text { rate in } \\
\mathrm{cm} / \text { year }\end{array}$ & $\begin{array}{l}\text { Diffusivity } \\
\mathrm{cm}^{2} / \mathrm{s}\end{array}$ \\
\hline 1 & \multirow{6}{*}{$\begin{array}{l}\text { Cadmium } \\
\text { load (3015) }\end{array}$} & 0 & 4.9 & 5.38 & 0 & 0 & 0 & 4.92 & 7.25 & 0 & 0 & 0 \\
\hline 2 & & 0.5 & 4.9 & 5.38 & 12.6 & 7.5811 & 0 & 4.92 & 7.25 & 0.002 & 0.7680 & 0 \\
\hline 3 & & 2 & 4.9 & 5.38 & 36 & 5.3606 & $1.76 \mathrm{E}-03$ & 4.92 & 7.25 & 0.004 & 1.4612 & $1.30 \mathrm{E}-04$ \\
\hline 4 & & 4 & 4.9 & 5.38 & 65.6 & 4.8047 & $1.90 \mathrm{E}-03$ & 4.92 & 7.25 & 0.003 & 1.1586 & $1.10 \mathrm{E}-04$ \\
\hline 5 & & 8 & 4.9 & 5.38 & 127 & 4.5548 & $7.24 \mathrm{E}-04$ & 4.92 & 7.25 & 0.003 & 0.9206 & $2.96 \mathrm{E}-05$ \\
\hline 6 & & 24 & 4.9 & 5.38 & 274.2 & 3.1812 & $9.97 \mathrm{E}-03$ & 4.92 & 7.25 & 0.001 & 0.3445 & $1.17 \mathrm{E}-04$ \\
\hline
\end{tabular}

Table 6 Leaching behavior with caged TCLP for $\mathrm{Ni}^{2+}$

\begin{tabular}{|c|c|c|c|c|c|c|c|c|c|c|c|c|}
\hline \multirow[t]{2}{*}{ S1. no. } & \multirow{2}{*}{$\begin{array}{l}\text { Heavy metal } \\
(\mathrm{mg} / \mathrm{kg})\end{array}$} & \multirow{2}{*}{$\begin{array}{l}\text { Time } \\
\text { (h) }\end{array}$} & \multicolumn{5}{|c|}{ Red soil (RS) } & \multicolumn{5}{|c|}{$\mathrm{RS}+\mathrm{X} \% \mathrm{NCS}$} \\
\hline & & & $\begin{array}{l}\text { Initial } \\
\mathrm{pH}\end{array}$ & $\begin{array}{l}\text { Final } \\
\mathrm{pH}\end{array}$ & $\begin{array}{l}\text { Amount } \\
\text { leached } \\
\mathrm{mg} / \mathrm{L}\end{array}$ & $\begin{array}{l}\text { Leaching } \\
\text { rate in } \\
\mathrm{cm} / \text { year }\end{array}$ & $\begin{array}{l}\text { Diffusivity } \\
\mathrm{cm}^{2} / \mathrm{s}\end{array}$ & $\begin{array}{l}\text { Initial } \\
\mathrm{pH}\end{array}$ & $\begin{array}{l}\text { Final } \\
\text { pH }\end{array}$ & $\begin{array}{l}\text { Amount } \\
\text { leached } \\
\mathrm{mg} / \mathrm{L}\end{array}$ & $\begin{array}{l}\text { Leaching } \\
\text { rate in } \\
\mathrm{cm} / \text { year }\end{array}$ & $\begin{array}{l}\text { Diffusivity } \\
\mathrm{cm}^{2} / \mathrm{s}\end{array}$ \\
\hline 1 & \multirow{6}{*}{$\begin{array}{l}\text { Nickel load } \\
\text { (3010) }\end{array}$} & 0 & 4.9 & 5.58 & 0 & 0 & 0 & 4.91 & 7.68 & 0.075 & 0 & 0 \\
\hline 2 & & 0.5 & 4.9 & 5.58 & 1.325 & 0.80336 & 0 & 4.91 & 7.68 & 1.32 & 0.78433 & 0 \\
\hline 3 & & 2 & 4.9 & 5.58 & 2.264 & 0.34043 & $7.08 \mathrm{E}-06$ & 4.91 & 7.68 & 1.74 & 0.25531 & $4 \mathrm{E}-06$ \\
\hline 4 & & 4 & 4.9 & 5.58 & 7.81 & 0.57771 & $2.74 \mathrm{E}-05$ & 4.91 & 7.68 & 4.3 & 0.31155 & $8 \mathrm{E}-06$ \\
\hline 5 & & 8 & 4.9 & 5.58 & 52.08 & 1.90250 & $1.26 \mathrm{E}-04$ & 4.91 & 7.68 & 5.44 & 0.19460 & $1 \mathrm{E}-06$ \\
\hline 6 & & 24 & 4.9 & 5.58 & 95.28 & 1.14576 & $1.29 \mathrm{E}-03$ & 4.91 & 7.68 & 6.1 & 0.07243 & $5 \mathrm{E}-06$ \\
\hline
\end{tabular}

Table 7 Leaching behavior with caged TCLP for $\mathrm{Pb}^{2+}$

\begin{tabular}{|c|c|c|c|c|c|c|c|c|c|c|c|c|}
\hline \multirow[t]{2}{*}{ S1. no. } & \multirow{2}{*}{$\begin{array}{l}\text { Heavy } \\
\text { metal } \\
(\mathrm{mg} / \mathrm{kg})\end{array}$} & \multirow{2}{*}{$\begin{array}{l}\text { Time } \\
\text { (h) }\end{array}$} & \multicolumn{5}{|c|}{ Red soil (RS) } & \multicolumn{5}{|c|}{$\mathrm{RS}+\mathrm{X} \% \mathrm{NCS}$} \\
\hline & & & $\begin{array}{l}\text { Initial } \\
\mathrm{pH}\end{array}$ & $\begin{array}{l}\text { Final } \\
\text { pH }\end{array}$ & $\begin{array}{l}\text { Amount } \\
\text { leached } \\
\mathrm{mg} / \mathrm{L}\end{array}$ & $\begin{array}{l}\text { Leaching } \\
\text { rate in } \\
\mathrm{cm} / \text { year }\end{array}$ & $\begin{array}{l}\text { Diffusivity } \\
\mathrm{cm}^{2} / \mathrm{s}\end{array}$ & $\begin{array}{l}\text { Initial } \\
\mathrm{pH}\end{array}$ & $\begin{array}{l}\text { Final } \\
\mathrm{pH}\end{array}$ & $\begin{array}{l}\text { Amount } \\
\text { leached } \\
\mathrm{mg} / \mathrm{L}\end{array}$ & $\begin{array}{l}\text { Leaching } \\
\text { rate in } \\
\mathrm{cm} / \text { year }\end{array}$ & $\begin{array}{l}\text { Diffusivity } \\
\mathrm{cm}^{2} / \mathrm{s}\end{array}$ \\
\hline 1 & \multirow{6}{*}{$\begin{array}{l}\text { Lead load } \\
\text { (3015) }\end{array}$} & 0 & 5.25 & 5.65 & 0 & 0 & 0 & 4.93 & 6.85 & 0 & 0 & 0 \\
\hline 2 & & 0.5 & 5.25 & 5.65 & 5.81 & 3.44302 & 0 & 4.93 & 6.85 & 2.5 & 1.484 & 0 \\
\hline 3 & & 2 & 5.25 & 5.65 & 13.53 & 1.98023 & $2.4 \mathrm{E}-04$ & 4.93 & 6.85 & 3.06 & 0.442 & $1.20 \mathrm{E}-05$ \\
\hline 4 & & 4 & 5.25 & 5.65 & 22.45 & 1.61605 & $2.1 \mathrm{E}-04$ & 4.93 & 6.85 & 4.12 & 0.295 & $7.13 \mathrm{E}-06$ \\
\hline 5 & & 8 & 5.25 & 5.65 & 51.95 & 1.84652 & $1.2 \mathrm{E}-04$ & 4.93 & 6.85 & 5.2 & 0.182 & $1.16 \mathrm{E}-06$ \\
\hline 6 & & 24 & 5.25 & 5.65 & 97.5 & 1.14063 & $1.3 \mathrm{E}-03$ & 4.93 & 6.85 & 8.7 & 0.100 & $9.89 \mathrm{E}-06$ \\
\hline
\end{tabular}

6. As per USEPA, a leachability index (LI) of more than 6 is considered as better material to arrest the transport of contaminants, and in our study, the leachability index (LI) for amended soils varies between 5 and 6; this confirms that the material is attenuating or retaining heavy metals, but there needs to be a small increase in the percentage of NCS added to soil which shall increase the value of LI to more than 6 as per USEPA standards [16, 19, 23, 24, 27].

\section{Sequential extraction}

Sequential extraction techniques present an arbitrary way of separating different metal species; this is because, the reagents are not very selective toward the particular species and rarely completely solubilize species. But the sequential extraction technique provides information on the origin, mode of occurrence, biological and physicochemical availability, mobilization and transport of metals in soils 
Table 8 Sequential extraction of $\mathrm{Cd}^{2+}, \mathrm{Ni}^{2+}$ and $\mathrm{Pb}^{2+}$

\begin{tabular}{|c|c|c|c|c|c|c|}
\hline \multirow[t]{2}{*}{ Extraction agents } & \multicolumn{3}{|l|}{$\mathrm{RS}$} & \multicolumn{3}{|c|}{$\mathrm{RS}+\mathrm{X} 3 \% \mathrm{NCS}$} \\
\hline & $\mathrm{Ni}^{+2} \%$ & $\mathrm{~Pb}^{+2} \%$ & $\mathrm{Cd}^{+2} \%$ & $\mathrm{Ni}^{+2} \%$ & $\mathrm{~Pb}^{+2} \%$ & $\mathrm{Cd}^{+2} \%$ \\
\hline \multicolumn{7}{|l|}{ Sequential extraction procedure } \\
\hline Soluble and exchangeable (F1) & 12.37 & 7.37 & 16.88 & 10.52 & 4.65 & 15.18 \\
\hline Bound to carbonates (F2) & 4.77 & 14.73 & 13.69 & 3.53 & 7.32 & 9.66 \\
\hline Bound to Fe/Mn oxides (F3) & 52.76 & 47.51 & 42.77 & 48.06 & 37.83 & 35.34 \\
\hline Bound to organic matter $(\mathrm{F} 4)$ & 27.42 & 26.69 & 23.63 & 28.64 & 28.74 & 21.02 \\
\hline Bound to soil matrix/residual (F5) & 2.68 & 3.7 & 3.03 & 9.25 & 21.46 & 18.8 \\
\hline
\end{tabular}

and amended soils. As reported in Table 8, the results obtained are represented in terms of percentage metal present in each soil phase. It was observed that the F1 representing weakly acidic condition and F2 reducing condition, F3 oxidizing condition. It can be observed that the mobility of the metals decrease approximately in the order of the extraction sequence. The main aim of this extraction test was to ascertain the amount of encapsulation taking place in the crystal lattices of mineral and crystallized oxides. It can be observed that in the residual fractions (F5), RS with NCS has maximum amount of metal ions in it with $\mathrm{Pb}$ being the highest of $21.46 \%$ followed by 18.8 and 9.25 of $\mathrm{Cd}$ and $\mathrm{Ni}$, respectively, whereas untreated RS retains only $3.7 \%, 3.03$ and 2.68 for $\mathrm{Pb}, \mathrm{Cd}$ and $\mathrm{Ni}$, respectively. This proves that encapsulation of heavy metals gets enhanced with the addition of NCS $[10,25,26]$.

\section{Micro-structural characterization}

Assistance of advanced measurement techniques has been taken to characterize materials at a micro-scale. The application of micro-structural material characterization for the identification of key elements which provide an opportunity to understand fundamental behavior of liner materials is demonstrated. Two local soils were considered in this study: red soil from Bangalore and black cotton soil from Belgaum of Karnataka state, India. To enhance their retentive capacities, nano calcium silicate was added. Heavy metals such as lead, nickel and cadmium were added leaching, and batch adsorption studies were conducted. These experimental results were confirmed by micro-structural studies using scanning electron microscopy (SEM) and energy dispersive spectroscopy (EDS or EDAX) on soil and soil mixtures using leached samples. Through the SEM images, it was easier to see the contrast between the grain texture and structure of the soil sample [15].

EDS scanning results show the composition of material which was predominantly quartz, from the large Si peaks; it also contains alumina and iron. The presence of iron represents the red color of the soil. The regular porous sponge-like particle crystals seems to be of alumino silicate, which is a major constituent of zeolite, a good adsorbent. The EDS data also show distinct peak of oxygen followed by silica, alumina and iron, respectively (Fig. 3a). The EDS data of pure soils without any contaminant addition showed no presence of heavy metals, whereas the EDS data of soils and soil mixtures, mixed with contaminants show very clearly the distinct presence of $\mathrm{Pb}, \mathrm{Cd}$, and $\mathrm{Ni}$ for the mixtures considered. It can be concluded that adsorption has taken place which, in turn, conforms well with experimental work carried out at macro-scale. Soils with nano calcium silicate mixtures adsorbed more of the selected heavy metals due to encapsulation, hydrolysis and precipitation of heavy metals. Soils also sorbed the selected heavy metals, but their degree of sorption was lower than amended soils. Figure $3 b$ represents the SEM and EDS of nano calcium silicate, it can be observed that the particles are porous and dumb-bell shaped and covering a large area because of their nano size. There is distinct presence of calcium and silica and also presence of oxygen. In terms of crystallography, it can also be observed (Fig. 3) wherein NCS is mixed as an amendment to red soil to retain the selected heavy metals that there are relatively long and narrow rods with parallel sides and no branching. The interlocking of crystalline structure can cause significant strength gains in stabilized soils, and this is called an $\mathrm{AFt}$ phase. In SEM studies of stabilized soils, the morphologies of neo-formed phases can be addressed under the common classes, namely aluminate ferrite tri (AFt), calcium hydrate $(\mathrm{CH})$, aluminate ferrite mono- (AFm) and calcium silicate hydrate $(\mathrm{C}-\mathrm{S}-\mathrm{H})$. The basis for this system is the common lattice structure of evolving crystallites in cementitious reaction which is related to observed morphology by the laws of crystallography [3, 30, 32].

\section{Mechanism of encapsulation and economic analysis}

The mechanism for enhanced immobilization capacity when soils are amended with NCS is due to sorption and entrapment of heavy metals in the newly formed 
(a)
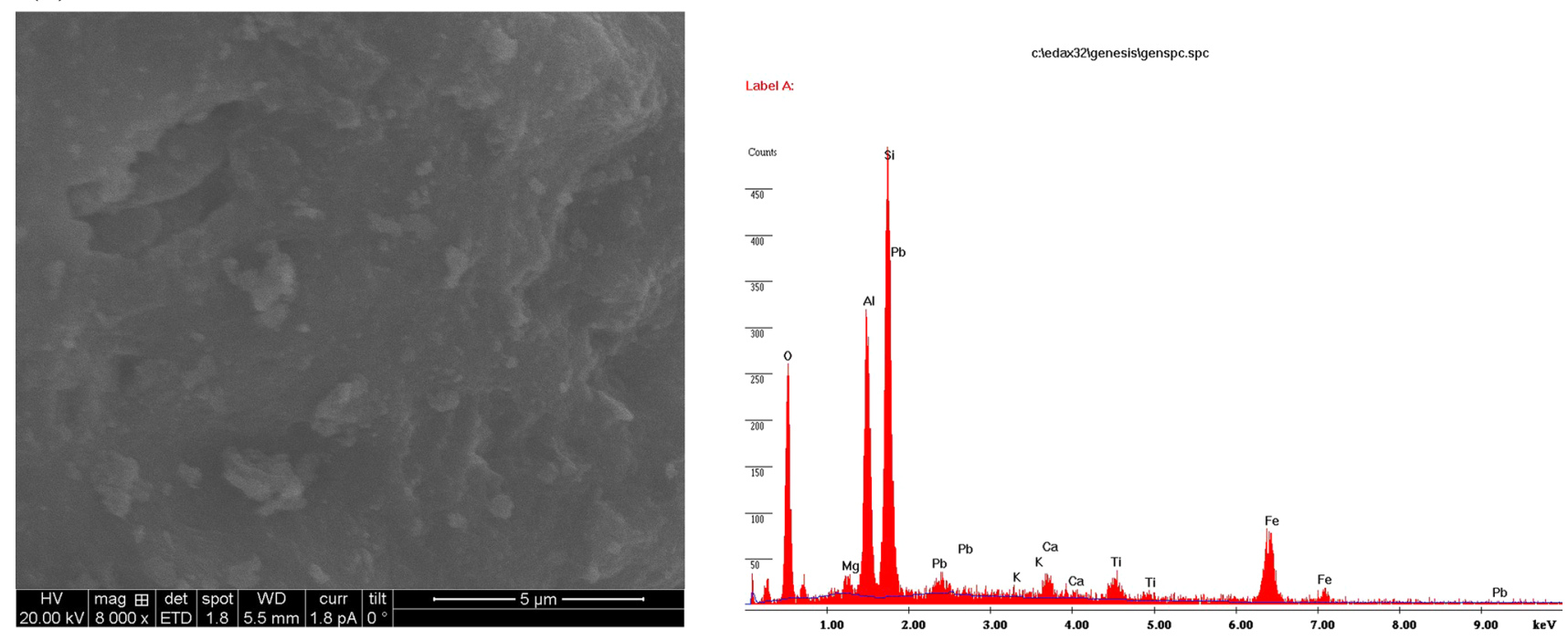

(b)
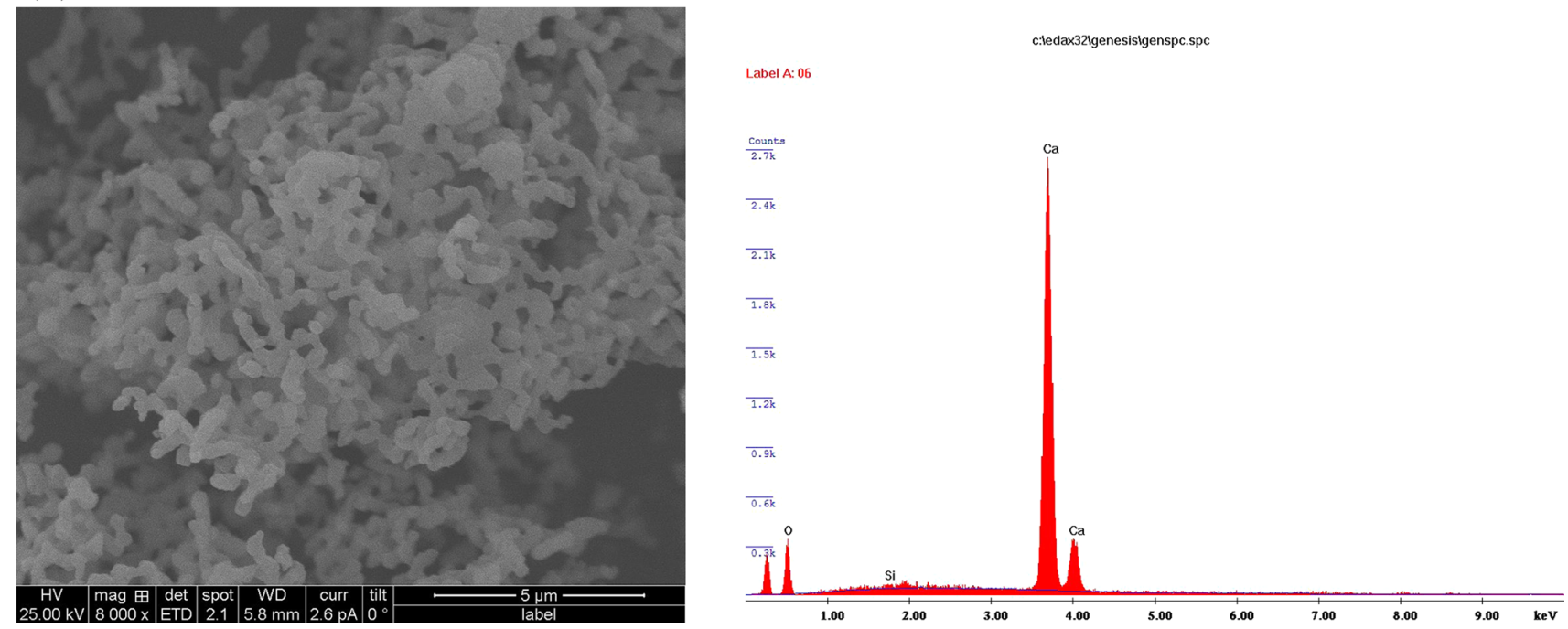

Fig. 3 a SEM and EDAX of red soil $+\mathrm{NCS}$ with $\mathrm{Pb}^{2+}$, b SEM and EDAX of nano calcium silicate

Fig. 4 Probable phenomenon of encapsulation of heavy metals with nano calcium silicate

\section{Nano Calcium Silicate and Soil}

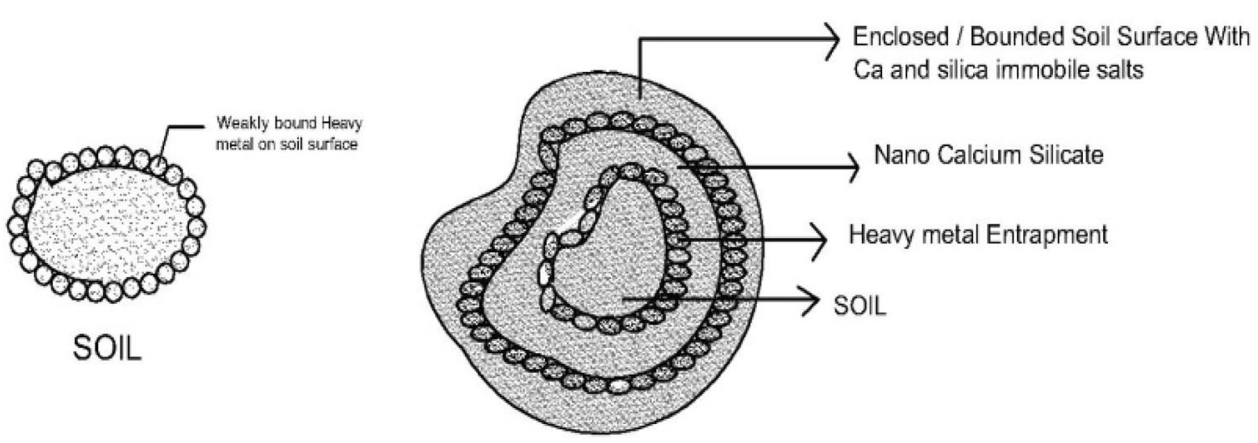


aggregates. This is because of aggregation of soil particles which encloses and binds with $\mathrm{Ca}$ - and $\mathrm{Si}$-associated immobile salts as shown in Fig. 4. Heavy metals are sorbed by soil co-ordination process. Heavy metal complex diffuses within the crystalline reticulum of soil particles leading to efficient entrapment of heavy metals due to the presence of NCS. It produces immobile salts with moisture and $\mathrm{CO}_{2}$ of atmosphere giving properties similar to pozzalonic cement and hydraulic properties. This results in heavy metal being brought into immobile $\mathrm{Ca}$ and $\mathrm{Si}$ salts. Hence, the soil surface binds/encloses into immobile Caand Si-associated salts.

Finally, results show clearly that leachable heavy metals decrease substantially after NCS mixture treatment to concentrations that are lower than the soil leachate regulatory standard limits of $5 \mathrm{mg} / \mathrm{L}$ for $\mathrm{Pb}^{2+}$ and $1 \mathrm{mg} / \mathrm{L}$ for $\mathrm{Cd}^{2+}$ as per EPA. The addition of NCS mixture might be applicable for remediation of heavy metal contaminated soil. Furthermore, to treat 1 ton of contaminated soil, NCS cost would be approximately 3000 USD. Also, the longterm effects of this mixture is worthy of investments as this gives a permanent solution. This method uses only existing moisture in soil; however, cement-based solidification occurs slowly and requires excess of water to solidify while additional treatment costs are involved for gene rating secondary effluents from cement-based $\mathrm{S} / \mathrm{S}$ techniques $[17,29]$.

\section{Conclusions}

This study was carried out to evaluate the nano calcium silicate (NCS) dispersion mixture as an immobilization treatment for heavy metal-contaminated soils. The results obtained in this study suggest that NCS is a suitable treatment for the gentle immobilization of heavy metals in polluted soils. This study was conducted on two soil types, one was a kaolinitic soil (red soil) which is mostly an inorganic soil and the other being montmorillonitic soil (black cotton soil) containing a higher amount of organics. It was found that NCS is effective on both the soils, but due to the expansive nature of black cotton soil, red soil is the preferred for most of the liner materials. Red soil amended with NCS in small percentage has been found to be a prospective material to attenuate heavy metals permanently; this was confirmed with a series of rigorous leaching tests. Further, a non-dimensional leachability index was calculated based on caged TCLP tests and was found to vary between 2 and 4 for virgin soils, and for soils amended with nano calcium silicate (NCS), it varied between 5 and 6 . This was further reinforced with microstructural studies which confirmed the role of different constituents of soil such as iron, alumina, calcium and silica in encapsulating the heavy metal. Hence, it can be concluded that this combination (Soil + NCS) can be used on soils available globally having similar properties as a prospective material to retain heavy metals.

Acknowledgments This paper is part of a research project supported by Science and Engineering Research Board (SERB), Department of Science and Technology (DST), Govt. of India, Project No. SR/S3/ MERC/0111/2012. The authors would also like to thank Mr. Kotresha $\mathrm{K}$, Junior Research Fellow (JRF) for his assistance in conducting the experiments.

\section{References}

1. Alpaslan B, Yukselen MA (2002) Remediation of lead contaminated soils by stabilization/solidification. Water Air Soil Pollut 33:253-263

2. ASTM (American Standard Testing Methods) (2012) Standard practice for shake extraction of solid waste with water D3987. West Conshohocken, PA

3. Bayat B (2002) Combined removal of zinc (II) and cadmium (II) from aqueous solutions by adsorption onto high-calcium Turkish fly ash. Water Air Soil Pollut 136:69-92

4. Batchelor B (1990) Leach models: theory and application. J Hazard Mat 24(2-3):255-266

5. Beesley L, Marmiroli M (2011) The immobilisation and retention of soluble arsenic, cadmium and zinc by biochar. Environ Pollut 159(2):474-480

6. Berthelsen BO, Ardal L, Steinne E (1994) Mobility of heavy metals in pine forest soils as influenced by experimental acidification. Water Air Soil Pollut 7:29-48

7. Bhattacharyya KG, Gupta SS (2008) Sorption of a few heavy metals on natural and modified kaolinite and montmorillonite. Adv Coll Interface Sci 140(2):114-131

8. Chattopadhyay S, Randall PM (2003) Evaluation of chemically bonded phosphate ceramics for mercury stabilization of a mixed synthetic waste. USEPA/600/R-03/113

9. Çoruh S, Elevli S (2013) Assessment of leaching characteristics of heavy metals from industrial leach waste. Int J Miner Process 123:165-171

10. Damikouka I, Katsiri A, Galvez R, Dyer M, Dean SW (2009) Chemical speciation and heavy metal mobility in contaminated marine sediments. J ASTM Int 6(6):160-169

11. Harter RD (1983) Effect of soil pH on adsorption of lead, copper, zinc, and nickel. Soil Sci Soc Am J 47(1):47-51

12. Heike B (2004) Adsorption of heavy metal ions on soils and soils constituents. J Coll Interface Sci 277:1-18

13. Hernandez AB, Ferrasse J-H (2011) Mineralogy and leachability of gasified sewage sludge solid residues. J Hazard Mater 191(1-3):219-227

14. Johnston JH, Borrmann T, Rankin D, Cairns M et al (2007) Nano structured composite silicate and some novel applications. J Curr Appl Phys 8:504-507

15. Lo I, Tang C-I (2000) Leaching and microstructural analysis of cement-based solidified wastes. Environ Sci Technol 34(23):5038-5042

16. Moghal AAB, Reddy KR, Mohammed SAS, Shamrani MAA, Zahid WM (2017) Retention studies of arsenic from aqueous solutions by lime treated semi arid soils. Int $\mathrm{J}$ Geomate 12(29):2836-2843

17. Moghal AAB, Mohammed SAS, Shamrani MAA, Zahid WM (2014) Performance of soils and soil lime mixtures as liners to 
retain heavy metal ions in aqueous solutions. Geotech Spec Publ 241:160-169

18. Moghal AAB, Dafalla MA, Elkady TY, Al-Shamrani MA (2015) Lime leachability studies on treated expansive semi-arid soil. Int J Geomate 9(2):1467-1471

19. Moghal AAB, Shamrani MAA, Zahid WM (2015) Heavy metal desorption studies on the artificially contaminated Al-Qatif soil. Int J Geomate 8(2):1323-1327

20. Moghal AAB, Sivapullaiah PV (2012) Retention characteristics of $\mathrm{Cu}^{2+}, \mathrm{Pb}^{2+}$ and $\mathrm{Zn}^{2+}$ from aqueous solutions by two types of low lime fly ashes. J Toxic Environ Chem 94-10:1941-1953

21. Moghal AAB, Mohammed SAS, Basha BM, Shamrani MAA (2014) Surface complexation modeling for stabilization of an industrial sludge by alternate materials. Geotech Spec Publ 234:2235-2244

22. Mohammed SAS, Moghal AAB (2014) Soils amended with admixtures as stabilizing agent to retain heavy metals. Geotech Spec Publ 234:2216-2226

23. Mohammed SAS, Naik M (2010) Characteristics of metals in aqueous solution by local materials with additives as liners for waste containment facilities. $\mathrm{J}$ Water Environ Technol $8(1): 29-50$

24. Nemr AEL (2009) Potential of pomegranate husk carbon for $\mathrm{Cr}(\mathrm{VI})$ removal from wastewater: kinetic and isotherm studies. J Hazard Mater 161:132-141
25. Pandian N, Sridharan A, Rajasekhar C (2001) Heavy metal retention behavior of clayey soils. J Test Eval 29(4):361-370

26. Randall P, Chattopadhyay S (2004) Advances in encapsulation technologies for the management of mercury-contaminated hazardous wastes. J Hazard Mater 114(1-3):211-223

27. Reddy KR (2010) Technical challenges to in situ remediation of polluted sites. Geotech Geol Eng J 28(3):211-221

28. Reddy KR, Danda S, Yükselen-Aksoy Y (2010) Sequestration of heavy metals in soils from two polluted industrial sites: implications on remediation. Land Contam Reclam J 18(1):13-23

29. Srinivasa R, Yoshiharu M, Tetsuji O et al (2012) Enhanced heavy metal immobilization in soil by grinding with addition of nanometallic $\mathrm{Ca} / \mathrm{CaO}$ dispersion mixture. $\mathrm{J}$ Chemosphere 89:717-723

30. Wilkinson A, Haque A, Kodikara J (2010) Stabilisation of clayey soils with industrial by-products: part A. Proceedings of the Institution of Civil Engineers. J Ground Improv 163(G13):149-163

31. Yong RN, MacDonald EM (1998) Adsorption of metals in geomedia. Influence of $\mathrm{pH}$, metal concentration and soil component removal on retention of $\mathrm{Pb}$ and $\mathrm{Cu}$ by an illitic soil. Academic press, pp 229-253

32. Zahid WM, Moghal AAB, Obaid AAK, Shamrani MAA, Mohammed SAS (2017) Physico chemical and geoenvironmental behavior of semi arid soils. Int J Geomate 12(29):115-123 